\title{
TREATMENT STRATEGIES AND OUTCOME OF PARVOVIRUS B19 INFECTION IN KIDNEY TRANSPLANT RECIPIENTS: A CASE SERIES AND LITERATURE REVIEW OF 128 PATIENTS
}

\author{
Rodrigo Rosado-Canto ${ }^{1 \neq}$, Diego L. Carrillo-Pérez ${ }^{1 \neq}$, José V. Jiménez ${ }^{1}$, Jennifer Cuellar-Rodríguez ${ }^{2}$, \\ IDalia Parra-Avila ${ }^{1}$, Josefina Alberú ${ }^{3}$ and luis E. Morales-Buenrostro ${ }^{1 *}$
}

Departments of ${ }^{1}$ Nephrology and Mineral Metabolism; ${ }^{2}$ Infectious Diseases, and ${ }^{3}$ Transplantation, Instituto Nacional de Ciencias Médicas y Nutrición Salvador Zubirán, Mexico City, Mexico.

¥These authors contributed equally to this study.

\begin{abstract}
Background: There is no specific antiviral treatment for parvovirus B19 (PVB19) infection. Objective: The objective of this study was to study the treatment and outcome of PVB19 infection in kidney transplant recipients (KTR) at our institution, and cases published in the medical literature. Methods: We conducted a retrospective review of PVB19 infection in KTR at an academic medical center over a 16-year period and summarized the data on its treatment and outcome in $120 \mathrm{KTR}$ in the medical literature. Results: In our cohort of eight patients, the median time to the onset of PVB19 disease was 7.2 weeks after transplantation. All patients had severe aregenerative anemia (mean hemoglobin $(\mathrm{Hb})$ of $6.2 \pm 1.0 \mathrm{~g} / \mathrm{dl}$ ); all were treated with a reduction in their immunosuppressive regimen and the administration of single-dose intravenous immunoglobulin (IVIG) (mean total dosage of $0.87 \pm 0.38 \mathrm{~g} / \mathrm{kg}$ ). The median time to anemia improvement $(\mathrm{Hb}>10 \mathrm{~g} / \mathrm{dl})$ was 3-week post-treatment. No recurrences were documented during follow-up (median 25 months). Among 128 patients (including our cohort of 8 and 120 reported in literature), therapeutic strategies included: $43 \%$ IVIG alone, 39\% IVIG and reduced immunosuppression, $9 \%$ reduction of immunosuppression, and $9 \%$ conservative therapy. Clinical relapses were observed in $35 \%$ of 71 reported cases. Conclusions: In KTR, decreasing immunosuppression and the administration of low-dose immunoglobulin seem to be not worse than the standard dose in PVB19 infection. (REV INVEST CLIN. 2019;71:265-74)
\end{abstract}

Key words: Human parvovirus B19. Kidney transplantation. Conservative treatment. Intravenous immunoglobulin. Treatment outcome.

Corresponding author:

*Luis E. Morales-Buenrostro

Department of Nephrology and Mineral Metabolism

Instituto Nacional de Ciencias Médicas

y Nutrición Salvador Zubirán

Vasco de Quiroga, 15

Col. Sección XVI, Del. Tlalpan

C.P.14080, Mexico City, Mexico

E-mail: luis_buenrostro@yahoo.com 


\section{INTRODUCTION}

Transplant recipients are susceptible to many primary viral infections and to the reactivation of persistent viruses. In the $1^{\text {st }}$ year post-transplantation, approximately $10 \%$ of kidney transplant recipients (KTR) have measurable Parvovirus B19 (PVB19) DNAemia in plasma samples without clinical manifestations. However, the incidence of symptomatic infection is very low ${ }^{1}$. Management of PVB19 infection is primarily symptomatic since there is no specific antiviral drug available for its treatment. In 1989, Kurtzman, et al. $^{2}$ reported the first successful treatment of PVB19 human infection with intravenous immunoglobulin (IVIG), and it later became the treatment of choice. Unfortunately, the optimal dosing and duration of IVIG therapy in PVB19 infection have not been established; furthermore, some patients have been reported to have long-lasting resolution of the infection without IVIG therapy ${ }^{3,4}$. The American Society of Transplantation recommends a reduction of immunosuppression at the time of diagnosis and $400 \mathrm{mg} / \mathrm{kg} /$ day of IVIG for 5 consecutive days ${ }^{5}$. However, there is no consensus in clinical practice on the ideal treatment of PVB19 infection. Based on these findings, the purpose of this study was to describe the treatment and outcome of PVB19 infection in KTR at our institution and summarize the data obtained in 120 cases published in the medical literature.

\section{PATIENTS AND METHODS}

\section{Study population}

We conducted a retrospective review of all cases of PVB19 infection among KTR at the Instituto Nacional de Ciencias Médicas y Nutrición Salvador Zubirán, a third-level academic hospital in Mexico City, from January 2000 to September 2016. We collected all pertinent information on their demographic characteristics, immunosuppressive (IS) regimens, clinical features, laboratory tests, bone marrow findings, adjustments in IS regimen, dose of IVIG therapy, and outcome (in terms of relapse, graft function, and mortality).

\section{Definitions}

PVB19 infection was defined according to the following criteria: (1) aregenerative severe anemia (reticulocyte production index $<2$, hemoglobin $(\mathrm{Hb})<10 \mathrm{~g} / \mathrm{dl}$ ) after transplantation, in the absence of hematologic disturbances or active bleeding and (2) qualitative or quantitative positive polymerase chain reaction (PCR) or a positive serologic assay (immunoglobulin M [lgM] antibodies) and/or positive immunohistochemistry in bone marrow biopsy with pure red cell aplasia (PRCA). Anemia improvement was defined as an $\mathrm{Hb}$ value $>10 \mathrm{~g} / \mathrm{dl}$.

\section{Induction and maintenance immunosuppression}

At our center, we use induction therapy according to the patient's immunologic risk. In high-risk KTR (e.g., positive pre-transplant donor-specific antibodies, highly sensitized, deceased donor transplantation, or second renal transplantation), we administer rabbit antithymocyte globulin (total dose $4.5 \mathrm{mg} / \mathrm{kg}$ ) plus methylprednisolone, and basiliximab (20 mg, at days 0 and 4) plus methylprednisolone in low-risk KTR. Maintenance IS includes triple-drug therapy with tacrolimus, mycophenolate mofetil, and prednisone.

\section{Review of literature}

We analyzed the medical literature for cases of PVB19 infection in KTR treated with IVIG by searching for articles published in PubMed and Medline databases from January 1989 to December 2017, with the following Medical Subject Headings terms: "human PVB19" and "kidney transplantation" (KT). The data on published cases were carefully collected according to a pre-established protocol.

\section{Statistical analysis}

We used descriptive statistics according to variable distribution. Categorical variables were compared using $\chi^{2}$ or Fisher's exact test when appropriate. A twotailed $p<0.05$ was considered statistically significant. All analyses were performed using the GraphPad Prism 5 software for Windows (Version 5.01).

\section{RESULTS}

\section{Summary of cases at our institution Demographic data}

A total of 795 patients who had received KT between January 2000 and September 2016 were analyzed. 
Table 1. Demographic, clinical characteristics, and outcome of eight patients with PVB19 infection after KT in our institution

\begin{tabular}{|c|c|c|c|c|c|c|c|c|}
\hline \multirow[t]{2}{*}{ Variable } & \multicolumn{8}{|c|}{ Patient } \\
\hline & 1 & 2 & 3 & 4 & 5 & 6 & 7 & 8 \\
\hline Age, years & 19 & 38 & 43 & 22 & 40 & 21 & 19 & 19 \\
\hline Sex & M & $\mathrm{F}$ & $\mathrm{F}$ & $\mathrm{F}$ & $\mathrm{F}$ & M & M & $\mathrm{F}$ \\
\hline Year of KT & 2004 & 2011 & 2012 & 2014 & 2014 & 2015 & 2015 & 2011 \\
\hline Type of KT & LD & LD & LD & LD & LD & DD & LD & DD \\
\hline $\begin{array}{l}\text { Type of IS } \\
\text { induction }\end{array}$ & $\begin{array}{l}\text { Daclizumab } \\
+ \text { MPD }\end{array}$ & $\begin{aligned} & \text { ATG } \\
+ & \text { MPD }\end{aligned}$ & MPD & $\begin{array}{l}\text { Basiliximab } \\
+ \text { MPD }\end{array}$ & $\begin{aligned} & \text { ATG } \\
+ & \text { MPD }\end{aligned}$ & $\begin{aligned} & \text { ATG } \\
+ & \text { MPD }\end{aligned}$ & $\begin{array}{l}\text { Basiliximab } \\
+ \text { MPD }\end{array}$ & $\begin{aligned} & \text { ATG } \\
+ & \text { MPD }\end{aligned}$ \\
\hline $\begin{array}{l}\text { TAC trough } \\
\text { levels from } \\
\text { KT to infection, } \\
\text { median } \\
\text { (range) } \mathrm{ng} / \mathrm{mL}\end{array}$ & $\begin{array}{c}8.4 \\
(6.4-11.3)\end{array}$ & $\begin{array}{c}11.2 \\
(3.5-14.1)\end{array}$ & $\begin{array}{c}15 \\
(6.0-25.1)\end{array}$ & $\begin{array}{c}7.4 \\
(6.4-9.5)\end{array}$ & $\begin{array}{c}6.9 \\
(3.9-11.3)\end{array}$ & $\begin{array}{c}15.2 \\
(3.3-19.8)\end{array}$ & $\begin{array}{c}6.9 \\
(2-30)\end{array}$ & $\begin{array}{c}8.3 \\
(5.1-16.5)\end{array}$ \\
\hline $\begin{array}{l}\text { Onset of } \\
\text { infection } \\
\text { after KT, } \\
\text { days }\end{array}$ & 54 & 39 & 34 & 94 & 43 & 105 & 29 & $2^{\prime} 045$ \\
\hline $\begin{array}{l}\text { PVB19 lgG/lgM } \\
\text { status at } \\
\text { infection } \\
\text { onset }\end{array}$ & $-/+$ & $+/-$ & $-/+$ & NP/NP & NP/NP & NP/NP & $+/-$ & NP/NP \\
\hline $\begin{array}{l}\text { PVB19, PCR } \\
\text { result }\end{array}$ & NP & NP & $>100,000,000$ & $2,133,090$ & + & + & + & + \\
\hline $\begin{array}{l}\text { Bone marrow } \\
\text { findings }\end{array}$ & NP & PRCA & NP & NP & PRCA & NP & NP & $\begin{array}{l}\text { HBM } \\
+ \text { MEC }\end{array}$ \\
\hline $\begin{array}{l}\text { Lowest } \mathrm{Hb} \\
\text { level, g/dl }\end{array}$ & 5.6 & 5.4 & 7 & 7.7 & 5.4 & 6.8 & 7.1 & 4.9 \\
\hline Leukopenia & Yes & No & Yes & Yes & No & No & Yes & Yes \\
\hline $\begin{array}{l}\text { Lowest WBC } \\
\text { count, } \times 109 / \mathrm{L}\end{array}$ & 1.8 & $\neg-$ & 4 & 3.6 & $-\neg$ & $-\neg$ & 3.3 & 2.2 \\
\hline Symptoms & Fever & $\begin{array}{l}\text { Dyspnea, } \\
\text { weakness }\end{array}$ & Fever & $\begin{array}{l}\text { Dyspnea, } \\
\text { weakness }\end{array}$ & $\begin{array}{l}\text { Dyspnea, } \\
\text { weakness }\end{array}$ & $\begin{array}{c}\text { Flu-like } \\
\text { symptoms }\end{array}$ & $\begin{array}{c}\text { Flu-like } \\
\text { symptoms }\end{array}$ & $\begin{array}{l}\text { Dyspnea, } \\
\text { weakness }\end{array}$ \\
\hline Treatment & $\begin{array}{l}\mathrm{IVIG} \text { and } \\
\text { reduced IS }\end{array}$ & $\begin{array}{l}\text { IVIG and } \\
\text { reduced IS }\end{array}$ & $\begin{array}{l}\mathrm{IVIG} \text { and } \\
\text { reduced IS }\end{array}$ & Reduced IS & $\begin{array}{l}\mathrm{IVIG} \text { and } \\
\text { reduced IS }\end{array}$ & $\begin{array}{l}\text { IVIG and } \\
\text { reduced IS }\end{array}$ & $\begin{array}{l}\mathrm{IVIG} \text { and } \\
\text { reduced IS }\end{array}$ & $\begin{array}{l}\text { IVIG and } \\
\text { reduced IS }\end{array}$ \\
\hline $\begin{array}{l}\text { IVIG total } \\
\text { dose, g }\end{array}$ & 80 & 24 & 30 & - & 84 & 48 & 48 & 50 \\
\hline $\begin{array}{l}\text { IVIG dosage, } \\
\text { g/kg/day }\end{array}$ & 1.45 & 0.4 & 0.43 & - & 1.12 & 1.06 & 0.76 & 0.86 \\
\hline $\begin{array}{l}\text { Days } \\
\text { improvement } \\
\text { anemia }^{a}\end{array}$ & 12 & 60 & 19 & 17 & 22 & 20 & 24 & 36 \\
\hline $\begin{array}{c}\text { Recurrence } \\
\text { of PVB19 } \\
\text { infection }\end{array}$ & No & No & No & No & No & No & No & No \\
\hline $\begin{array}{l}\text { Graft } \\
\text { dysfunction }\end{array}$ & No & No & No & No & No & No & No & Yes \\
\hline $\begin{array}{l}\text { Months of } \\
\text { follow-up }\end{array}$ & 155 & 22 & 62 & 43 & 22 & 5 & 28 & 16 \\
\hline
\end{tabular}

${ }^{a}$ Anemia improvement was defined with hemoglobin $>10 \mathrm{~g} / \mathrm{dL}$. M: Male, F: Female, KT: Kidney transplantation, LD: Living donor, DD: Deceased donor, IS: Immunosuppression, ATG: Rabbit antithymocyte globulin, MPD: Methylprednisolone, TAC: Tacrolimus, + or -: Positive or negative, NP: Not performed, PRCA: Pure red cell aplasia, HBM: Hypocellular bone marrow, MEC: Megaloblastic erythroid cells, Hb: Hemoglobin, WBC: White blood cell, IVIG: Intravenous immunoglobulin, PVB19: Parvovirus B19. 
Over a 16-year period, eight patients with PVB19 infection were identified. The clinical data, treatment, and outcome of our case series are described in Table 1. Patient mean age was $28.1 \pm 10.3$ years, $6(75 \%)$ were living donor KTR, and 7 (88\%) were receiving triple IS therapy with prednisone, tacrolimus, and mycophenolate mofetil. The median time to the onset of PVB19 infection was 7.2 weeks (range, 4.1-292 weeks) after transplantation. 7 (88\%) patients developed the infection within the first 4 months after transplantation, and only one patient had late-onset (6 years after KT) infection after having received treatment for active humoral rejection (plasma exchange, IVIG, rituximab, and bortezomib). At the time of diagnosis, the median tacrolimus trough levels were 9.4 (range, $2-30$ ) $\mathrm{ng} / \mathrm{mL}$.

\section{Clinical features}

All patients had hypoproliferative anemia (mean $\mathrm{Hb}$ value, $6.2 \pm 1.0 \mathrm{~g} / \mathrm{dL}$ ) and $5(62 \%)$ patients had leukopenia (median leukocyte count 3.3, 1.8-4 × 10\%/L). $6(75 \%)$ patients required blood transfusion with a median of 2 (range 1-3) units of packed red blood cells per patient. No patient presented with skin, neurological, or cardiac involvement.

\section{Diagnosis}

PVB19 testing was performed when clinical diagnosis was considered. In six cases, the diagnosis was established by PCR (75\%). Positive IgM antibodies and positive immunohistochemical staining in the bone marrow biopsy were found in one patient for each test, respectively. Only three patients had bone marrow examination; two had PRCA and one had a hypocellular bone marrow and megaloblastic erythroid cells.

\section{Treatment}

After diagnosis, the IS regimen was decreased in all patients: the antiproliferative drug (mycophenolate mofetil or azathioprine) was discontinued in $6(75 \%)$ patients and in $2(25 \%)$, the dosage was halved and tacrolimus was reduced to achieve trough levels of approximately $5 \mathrm{ng} / \mathrm{mL} .7$ ( $88 \%$ ) patients received single-dose IVIG at a mean total dose of $0.87 \pm$ $0.38 \mathrm{~g} / \mathrm{kg}$.

\section{Outcome}

After these interventions, $\mathrm{Hb}$ levels improved progressively in all subjects. The median time to anemia improvement was 3 weeks (range, 1.7-8.6 weeks) posttreatment (Fig. 1). The median follow-up period after treatment of PVB19 infection was 25 months (range, 5-155). No subjects relapsed, developed graft loss, or died during PVB19 infection. No adverse events relating to IVIG administration were observed during or after the infusion.

\section{Review of literature}

Table 2 lists the clinical data, treatment, and outcome of 128 cases of KTR with PVB19 infection, including our patients ${ }^{3,4,6-53}$. The median time to PVB19 infection was 2 months (interquartile range, 1-6) and the most common manifestation was anemia in 96 (75\%) patients. $10(8 \%)$ patients had thrombotic microangiopathy, 9 (7\%) pancytopenia, 3 (2\%) hepatitis, 2 (1.5\%) encephalitis, $2(1.5 \%)$ hemophagocytic syndrome, and $1(0.8 \%)$ collapsing glomerulopathy. Among the 128 patients, the therapeutic strategies included: (1) IVIG only ( $n=54,43 \%)$, (2) IVIG and decreased IS ( $n=50$, $39 \%)$, (3) decreased IS only ( $n=12,9 \%$ ), and (4) conservative therapy, with transfusion and/or erythropoietin, or no treatment $(n=12,9 \%)$.

Follow-up data on clinical relapses were available in 71 patients, 25 (35\%) of whom relapsed. According to the therapeutic strategy, the recurrence rate was as follows: $18 / 44$ (41\%) for IVIG plus IS reduction, $6 / 16$ (35\%) for IVIG only, 1/6 (17\%) for IS reduction, and $0 / 5(0 \%)$ if there was no therapeutic intervention $(p=0.23)$.

\section{DISCUSSION}

We herein report the data obtained in a series of eight KTR with PVB19 infection in our center over a 16-year period, and the review of 120 additional cases obtained in literature. The patients' clinical characteristics were similar to other reports ${ }^{3,11,25}$, in which severe aregenerative anemia was the most common manifestation in the early post-transplant period (median time to infection was 2 months in the medical literature) and a median time to $\mathrm{Hb}$ recovery of 3 weeks ${ }^{3}$. 
Figure 1. Evolution of parvovirus B19-induced anemia in our cohort.

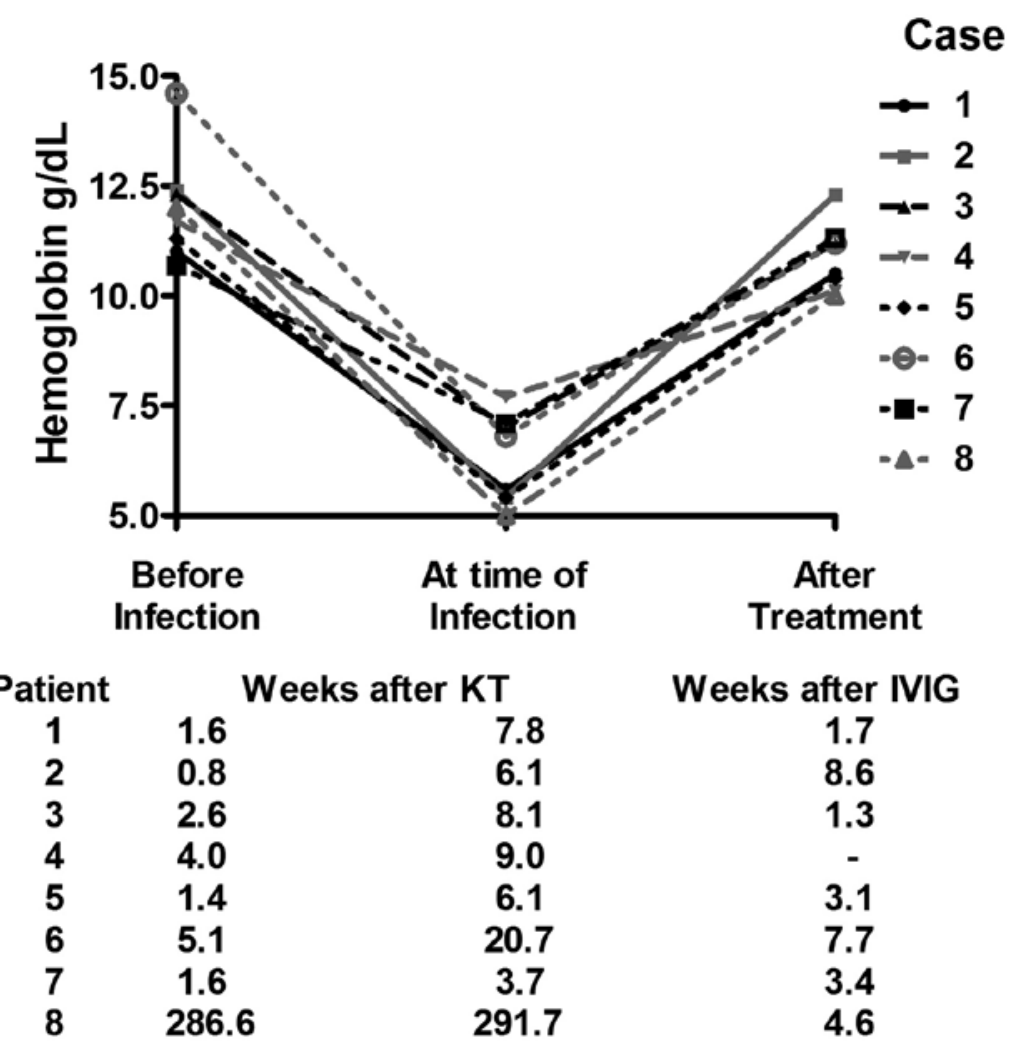

KT: Kidney transplant. IVIG: Intravenous immunoglobulin.

There is no specific antiviral therapy available to treat PVB19 infection. The treatment options in KTR described in the medical literature include: IVIG only, IVIG and decreased immunosuppression, reduction of immunosuppression only, and conservative therapy, including transfusions, erythropoietin, and/or surveillance 25,54 .

IVIG is an important source of anti-PVB19 antibodies; it provides passive immunity and has proven to be efficacious, although no controlled trials have compared the effectiveness of the different dose regimens. As described in Table 2, the reported dose of IVIG was highly variable. The American Society of Transplantation recommends $400 \mathrm{mg} / \mathrm{kg} /$ day of IVIG for 5 consecutive days and reduction of immunosuppression at the time of the PVB19 infection diagno$\mathrm{sis}^{5}$. In a review of the literature, Crabol, et al. ${ }^{11}$ reported that at an initial IVIG dose of $2.3 \pm 1.3 \mathrm{~g} / \mathrm{kg}$ could be effective in eradicating the PRCA associated to PVB19 infection. However, this analysis included a heterogeneous population of immunosuppressed subjects; only $47 \%$ were solid organ transplant recipients, while the remainders were patients with HIV infection (30\%), hematological (14\%), and systemic autoimmune and/or inflammatory diseases (5\%). In this series, IS was decreased in only $38 \%$ of patients (discontinuation of immunosuppressant in $32 \%$ and introduction of highly active antiretroviral therapy in $6 \%$ ). In non-modifiable immunosuppression states, higher doses could be the only treatment option in PVB19 infection. However, IVIG administration is frequently associated with a concomitant decrease in $I^{3,23,25}$. There is controversy on whether low-versus high-dose IVIG regimens are preferable, due to costeffectiveness and complications due to immune complex formation ${ }^{34}$. KTR is a potentially modifiable IS state, which could allow the use of lower doses of IVIG in association with reduction of IS.

There is no universal access to IVIG in the Mexican healthcare system. The out-of-pocket health expenditure (percentage of total health expenditure) is $44 \%$, which is much higher than in the USA or 
Table 2. Treatment and outcome of 128 cases of PVB19 infection in KTR

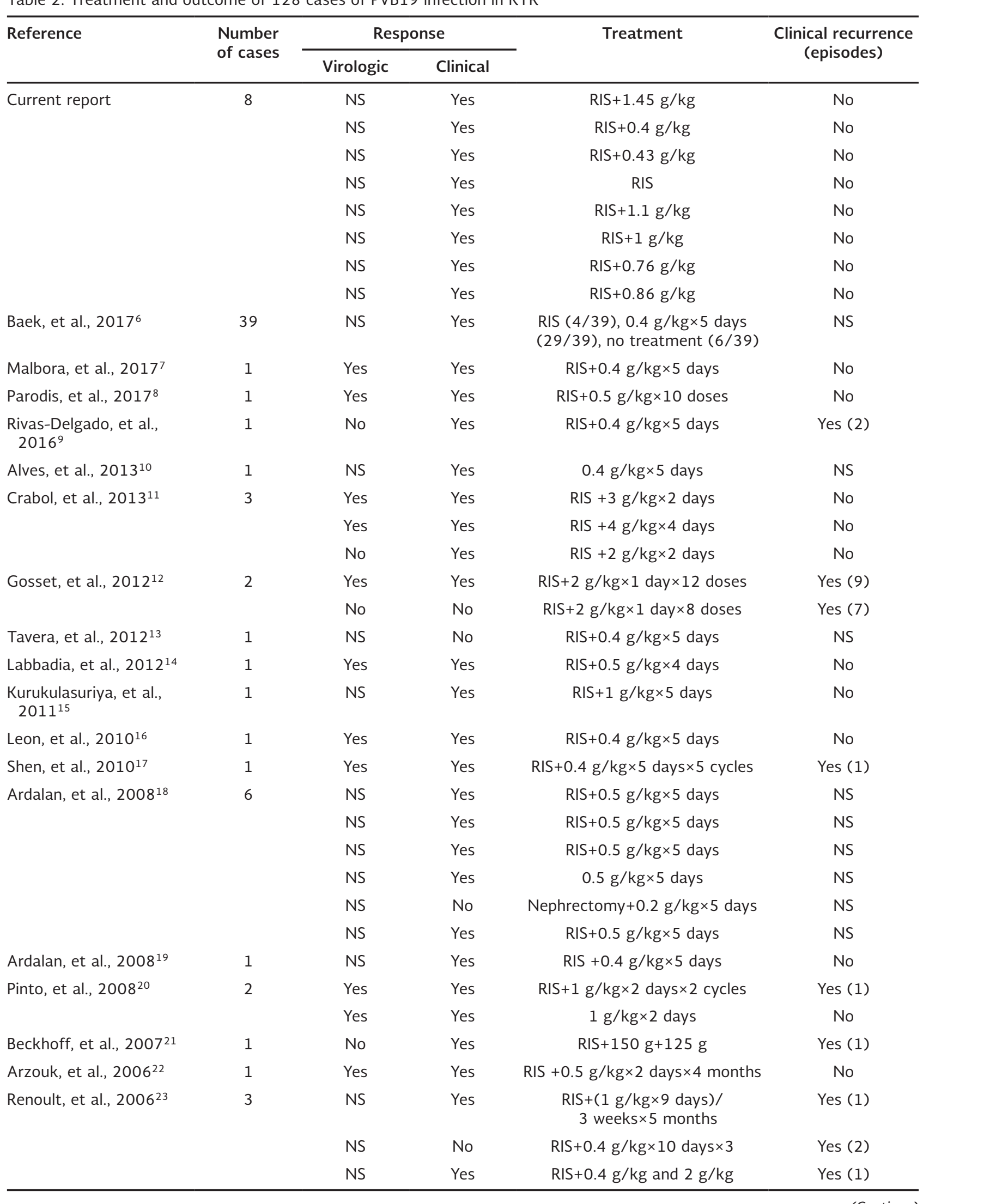


Table 2. Treatment and outcome of 128 cases of PVB19 infection in KTR (continued)

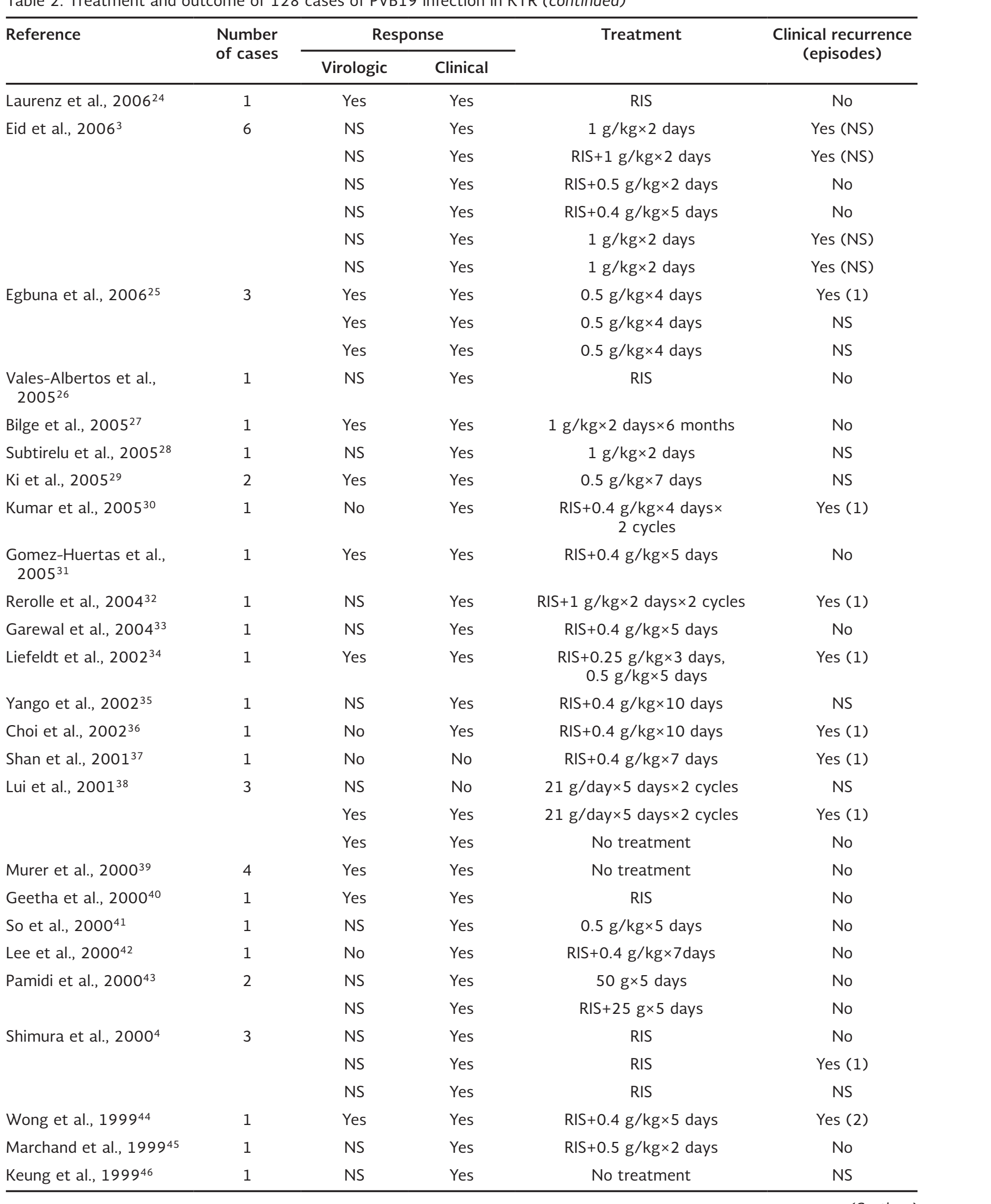


Table 2. Treatment and outcome of 128 cases of PVB19 infection in KTR (continued)

\begin{tabular}{|c|c|c|c|c|c|}
\hline \multirow[t]{2}{*}{ Reference } & \multirow{2}{*}{$\begin{array}{l}\text { Number } \\
\text { of cases }\end{array}$} & \multicolumn{2}{|c|}{ Response } & \multirow[t]{2}{*}{ Treatment } & \multirow{2}{*}{$\begin{array}{l}\text { Clinical recurrence } \\
\text { (episodes) }\end{array}$} \\
\hline & & Virologic & Clinical & & \\
\hline \multirow[t]{3}{*}{ Moudgil, et al., $1997^{47}$} & 3 & NS & Yes & $0.4 \mathrm{~g} / \mathrm{kg} \times 10$ days & Yes (1) \\
\hline & & NS & Yes & $0.4 \mathrm{~g} / \mathrm{kg} \times 10$ days & No \\
\hline & & NS & Yes & $\begin{array}{l}\text { RIS }+1 \mathrm{~g} / \mathrm{kg} \times 2 \text { days and then } \\
\text { every week for } 3 \text { months }\end{array}$ & Yes (1) \\
\hline Mathias, et al., $1997^{48}$ & 1 & NS & Yes & $\mathrm{RIS}+1 \mathrm{~g} / \mathrm{kg} \times 2$ days & No \\
\hline Ahsan, et al., $1997^{49}$ & 1 & Yes & Yes & $\mathrm{RIS}+0.4 \mathrm{~g} / \mathrm{kg} \times 5$ days & No \\
\hline Bertoni, et al., $1997^{50}$ & 4 & No & Yes & $0.4 \mathrm{~g} / \mathrm{kg} \times 15$ days & No \\
\hline Sturm, et al., $1996^{51}$ & 1 & No & Yes & $\mathrm{RIS}+0.4 \mathrm{~g} / \mathrm{kg} \times 4$ days & Yes (1) \\
\hline Uemura, et al.,199552 & 1 & No & Yes & $35 \mathrm{~g}$ & NS \\
\hline al-Khaldi, et al.,199453 & 1 & NS & Yes & No treatment & No \\
\hline
\end{tabular}

NS: Not specified, RIS: Reduction in immunosuppression, PVB19: Parvovirus B19, KTR: Kidney transplant recipient.

European Union ( 11 and $13.9 \%$, respectively), placing us as well as other low-income countries at a disadvantage in terms of access to health services ${ }^{55}$. The standard cost of the recommended IVIG dose (e.g., 2 $\mathrm{g} / \mathrm{kg}$ in an individual weighing $70 \mathrm{~kg}$ ) is approximately 10,216.34 USD and this amount grossly exceeds the monthly income of a Mexican family, 804 USD. The low dose of IVIG used in our series was due to the inability of patients or the health system to afford higher doses, although the outcome did not seem worse than in other reported series.

Our patients received a single total dose of IVIG (mean $0.87 \pm 0.42 \mathrm{~g} / \mathrm{kg}$ ) plus IS reduction, and none relapsed clinically. We cannot attribute the success rate and lack of recurrence to the dose of IVIG due to the associated IS reduction, an evident confounder. However, we believe that our cases may represent a model of reverse innovation, and its effectiveness could be generalized to low-income populations and be subsequently evaluated in high-income countries in multicenter controlled clinical trials ${ }^{56}$. Although IVIG is considered to be relatively safe, about $10-13 \%$ of patients develop side effects, mainly acute renal failure and pulmonary edema ${ }^{3,11}$.

This study underscores the need for the temporary decrease in IS, if feasible, as part of the treatment to allow the immune system to mount a specific immune response against PVB19 infection. Some investigators have reported success with reduction of IS alone $4,24,26,40$. Our population was predominantly at low risk for rejection, which allowed us to decrease IS (discontinuation or halving of antiproliferative drugs) and use low doses of IVIG (mean dose of $0.87 \pm 0.38 \mathrm{~g} / \mathrm{kg}$ ), with subsequent improvement in $\mathrm{Hb}$ and no relapses during follow-up. In contrast, Liefeldt, et al. ${ }^{34}$ failed to eradicate viremia in a patient with decreased IS and lowdose IVIG ( $0.25 \mathrm{~g} / \mathrm{kg}$ for 3 days), but he was successfully treated using higher doses of IVIG $(0.5 \mathrm{~g} / \mathrm{kg}$ for 5 days). Some authors reported spontaneous recovery in $\operatorname{KTR}^{39,45,46,53,57}$, suggesting that a conservative approach with blood transfusions, recombinant erythropoietin, or surveillance may be an option in those with less severe infections.

Clinical PVB19 infection relapses can occur many months after completion of any of the above therapies and are usually heralded by the reappearance of anemia. Factors fostering relapse include failure to eradicate fully the virus, degradation of exogenous IVIG, reintroduction of IS, or failure to mount a humoral and/or cellular immune response ${ }^{54}$. In our analysis of the KTR population, overall recurrence was $35 \%$, similar to that reported by Crabol, et al. ${ }^{11}$, in a heterogeneous population with $34 \%$ of relapses in initial responders over a mean time period of 4 months and that required an additional course of IVIG to achieve a sustained response rate at 12 months, all a result of their non-modifiable states of immunosuppression.

In our analysis, the relapse rates according to the type of therapeutic strategy included $41 \%$ in the group of 
IVIG plus IS reduction and 35\% in the group treated only with IVIG. These outcomes may be biased due to the tendency to publish successful cases in which the administered therapeutic strategy was different from the standard approach ( $17 \%$ relapses in the group with IS reduction and no relapses in patients with no therapeutic intervention) and more intensive treatment in patients with more relevant clinical PVB19 manifestations.

Our study was limited by its retrospective design. Furthermore, the available information on PVB19 infection in KTR is predominantly presented as case reports. Another potential limitation is the lack of serial quantitative PCR assays during follow-up, to evaluate virological behavior and the eradication of viremia. However, the value of such a monitoring has not been studied, and the improvement in $\mathrm{Hb}$ levels with treatment and no recurrence of anemia over a median follow-up of 2 years suggests the absence of virus replication.

In KTR, reduction of immunosuppression and the administration of low-dose immunoglobulin seem to be not worse than the standard dose in PVB19 infection.

\section{ACKNOWLEDGMENTS}

The authors gratefully acknowledge Deborah AlemánHoey MD, and Abraham Cohen MD, for their assistance in the review of this manuscript.

\section{REFERENCES}

1. Porignaux R, Vuiblet V, Barbe C, Nguyen Y, Lavaud S, Toupance $\mathrm{O}$, et al. Frequent occurrence of parvovirus B19 DNAemia in the first year after kidney transplantation. J Med Virol. 2013; 85:1115-21.

2. Kurtzman G, Frickhofen N, Kimball J, Jenkins DW, Nienhuis AW, Young NS, et al. Pure red-cell aplasia of 10 years' duration due to persistent parvovirus B19 infection and its cure with immunoglobulin therapy. N Engl J Med. 1989;321:519-23.

3. Eid AJ, Brown RA, Patel R, Razonable RR. Parvovirus B19 infection after transplantation: a review of 98 cases. Clin Infect Dis. 2006;43:40-8.

4. Shimmura H, Tanabe K, Ishikawa N, Tokumoto T, Toda F, Toma $H$, et al. Discontinuation of immunosuppressive antimetabolite for parvovirus B19-associated anemia in kidney transplant patients. Transplant Proc. 2000;32:1967-70.

5. Eid AJ, Chen SF, AST Infectious Diseases Community of Practice. Human parvovirus B19 in solid organ transplantation. Am J Transplant. 2013;13 Suppl 4:201-5.

6. Baek CH, Kim H, Yang WS, Han DJ, Park SK. Risk factors and long-term outcomes of parvovirus B19 infection in kidney transplant patients. Transpl Infect Dis. 2017;19:e12754.
7. Malbora B, Saritas S, Ataseven E, Belen B, Alparslan C, Yavascan $\mathrm{O}$, et al. Pure red cell aplasia due to parvovirus B19: erythropoietin-resistant anemia in a pediatric kidney recipient. Exp Clin Transplant. 2017;15:369-71.

8. Parodis López Y, Santana Estupiñán R, Marrero Robayna S, Gallego Samper R, Henríquez Palop F, Rivero Vera JC, et al. Anaemia and fever in kidney transplant. The role of human parvovirus B19. Nefrologia. 2017;37:206-12.

9. Rivas-Delgado A, Matutes E, Rozman M. Recurrent pure red cell aplasia in a hepatorenal transplant recipient with chronic parvovirus B19 infection. Br J Haematol. 2016;172:495.

10. Alves MT, Vilaça SS, Carvalho Md, Fernandes AP, Dusse LM, Gomes KB, et al. Human parvovirus B19 infection in a renal transplant recipient: A case report. BMC Res Notes. 2013;6:28.

11. Crabol Y, Terrier B, Rozenberg F, Pestre V, Legendre C, Hermine $\mathrm{O}$, et al. Intravenous immunoglobulin therapy for pure red cell aplasia related to human parvovirus b19 infection: A retrospective study of 10 patients and review of the literature. Clin Infect Dis. 2013;56:968-77.

12. Gosset C, Viglietti D, Hue K, Antoine C, Glotz D, Pillebout E, et al. How many times can parvovirus B19-related anemia recur in solid organ transplant recipients? Transpl Infect Dis. 2012; 14:E64-70.

13. Tavera M, Petroni J, León L, Minue E, Casadei D. Reactive haemophagocytic syndrome associated with parvovirus B19 in a kidney-pancreas transplant patient. Nefrologia. 2012;32:125-6.

14. Labbadia F, Salido-Fierréz E, Majado-Martinez J, Cabañas-Perianes V, Moraleda J]. Pure red cell aplasia in a simultaneous pancreas-kidney transplantation patient: inside the erythroblast. Hematol Rep. 2012;4:e17.

15. Kurukulasuriya A, Hamed AA, Al-Muslahi M, Ibrahim A. Acquired pure red cell aplasia caused by parvovirus B19 infection following a renal transplant. Sultan Qaboos Univ Med J. 2011; 11:280-3.

16. León LR, Curcio D, Casadei D. Parvovirus B19 infection: diagnosing and treating a kidney transplant patient. Nefrologia. 2010; 30:704.

17. Shen Q, Xu H, Cao Q, Zhou LJ, Xu J, Fang XY, et al. Long-term remission of recurrent severe anemia as a result of parvovirus B19 infection in a pediatric renal transplant recipient. Pediatr Transplant. 2011;15:E76-9.

18. Ardalan MR, Shoja MM, Tubbs RS, Jayne D. Parvovirus B19 microepidemic in renal transplant recipients with thrombotic microangiopathy and allograft vasculitis. Exp Clin Transplant. 2008;6:137-43.

19. Ardalan MR, Shoja MM, Tubbs RS, Esmaili H, Keyvani H. Postrenal transplant hemophagocytic lymphohistiocytosis and thrombotic microangiopathy associated with parvovirus b19 infection. Am J Transplant. 2008;8:1340-4.

20. Pinto V, Grandy J, Zambrano P, Corta B, Salas P, Salgado I, et al. Severe anemia from parvovirus b19 infection in pediatric renal transplant recipients: two case reports. Transplant Proc. 2008; 40:3261-4.

21. Beckhoff A, Steffen I, Sandoz P, Hirsch HH, Schaub S. Relapsing severe anaemia due to primary parvovirus B19 infection after renal transplantation: a case report and review of the literature. Nephrol Dial Transplant. 2007;22:3660-3.

22. Arzouk N, Snanoudj R, Beauchamp-Nicoud A, Mourad G, Charpentier B, Tchernia G, et al. Parvovirus B19-induced anemia in renal transplantation: a role for $\mathrm{rHuEPO}$ in resistance to classical treatment. Transpl Int. 2006;19:166-9.

23. Renoult E, Bachelet C, Krier-Coudert MJ, Diarrassouba A, André JL, Kessler M, et al. Recurrent anemia in kidney transplant recipients with parvovirus B19 infection. Transplant Proc. 2006; 38:2321-3.

24. Laurenz M, Winkelmann B, Roigas J, Zimmering M, Querfeld U Müller D, et al. Severe parvovirus B19 encephalitis after renal transplantation. Pediatr Transplant. 2006;10:978-81.

25. Egbuna O, Zand MS, Arbini A, Menegus M, Taylor J. A cluster of parvovirus B19 infections in renal transplant recipients: a prospective case series and review of the literature. Am J Transplant. 2006;6:225-31.

26. Vales-Albertos LJ, García-Cárdenas M, Chávez-Becerra S, Gómez-Navarro B, Monteón-Ramos F, Cueto-Manzano AM, et al. Pure red cell aplasia associated with parvovirus B19 infection in renal transplantation: the first case report in Mexico. Transplantation. 2005;79:739.

27. Bilge I, Sadikoğlu B, Emre S, Sirin A, Aydin K, Tatli B, et al. Central nervous system vasculitis secondary to parvovirus B19 infection in a pediatric renal transplant patient. Pediatr Nephrol. 2005; 20:529-33. 
28. Subtirelu MM, Flynn JT, Schechner RS, Pullman JM, Feuerstein D, Del Rio $M$, et al. Acute renal failure in a pediatric kidney allograft recipient treated with intravenous immunoglobulin for parvovirus B19 induced pure red cell aplasia. Pediatr Transplant. 2005;9:801-4.

29. Ki CS, Kim IS, Kim JW, Lee NY, Kim SH, Lee KW, et al. Incidence and clinical significance of human parvovirus B19 infection in kidney transplant recipients. Clin Transplant. 2005;19:751-5.

30. Kumar J, Shaver MJ, Abul-Ezz S. Long-term remission of recurrent parvovirus-B associated anemia in a renal transplant recipient induced by treatment with immunoglobulin and positive seroconversion. Transpl Infect Dis. 2005;7:30-3.

31. Gómez Huertas E, Melón S, Laurés AS, de Oña M, AlvarezGrande J. Parvovirus B9 infection in a renal transplant recipient. Diagnosis by detection of viral genome in peripheral blood. Nefrologia. 2005;25:67-72

32. Rerolle JP, Morelon E, Helal I, Peraldi MN, Mamzer-Bruneel MF, Kreis $\mathrm{H}$, et al. Parvovirus B19-related anaemia after renal transplantation. Scand J Infect Dis. 2004:36:513-6.

33. Garewal G, Ahluwalia J, Varma N, Das R, Sakhuja VK. Parvovirus B19 infection-associated red-cell aplasia in renal-transplant recipients: clues from the bone marrow. Transplantation. 2004;77:320-1.

34. Liefeldt L, Buhl M, Schweickert B, Engelmann E, Sezer O, Laschinski $P$, et al. Eradication of parvovirus B19 infection after renal transplantation requires reduction of immunosuppression and high-dose immunoglobulin therapy. Nephrol Dial Transplant. 2002;17:1840-2.

35. Yango A Jr, Morrissey P, Gohh R, Wahbeh A Donor-transmitted parvovirus infection in a kidney transplant recipient presenting as pancytopenia and allograft dysfunction. Transpl Infect Dis. 2002;4:163-6.

36. Choi SH, Chang SP, Won JC, Lee JS, Chi HS, Yang WS, et al. A case of persistent anemia in a renal transplant recipient: association with parvovirus B19 infection. Scand J Infect Dis. 2002;34:71-5.

37. Shan YS, Lee PC, Wang JR, Tsai HP Sung CM, Jin YT et al Fibrosing cholestatic hepatitis possibly related to persistent parvovirus B19 infection in a renal transplant recipient. Nephrol Dial Transplant. 2001;16:2420-2.

38. Lui SL, Luk WK, Cheung CY, Chan TM, Lai KN, Peiris JS, et al Nosocomial outbreak of parvovirus B19 infection in a renal transplant unit. Transplantation. 2001;71:59-64

39. Murer L, Zacchello G Bianchi D Dall'Amico R Montini G Andreetta $B$, et al. Thrombotic microangiopathy associated with parvovirus B 19 infection after renal transplantation. J Am Soc Nephrol. 2000;11:1132-7.

40. Geetha D, Zachary JB, Baldado HM, Kronz JD, Kraus ES. Pure red cell aplasia caused by parvovirus B19 infection in solid organ transplant recipients: a case report and review of literature. Clin Transplant. 2000;14:586-91.

41. So BJ, Chae KM, Lee KK, Lee YJ, Jeong BH. Pure red cell aplasia due to parvovirus B19 infection in a renal transplant patient: a case report. Transplant Proc. 2000;32:1954-6.
42. Lee PC, Hung CJ, Lei HY, Chang TT, Wang JR, Jan MS, et al. Parvovirus B19-related acute hepatitis in an immunosuppressed kidney transplant. Nephrol Dial Transplant. 2000 15:1486-8.

43. Pamidi S, Friedman K, Kampalath B, Eshoa C, Hariharan S. Human parvovirus B19 infection presenting as persistent anemia in renal transplant recipients. Transplantation. 2000;69:2666-9.

44. Wong TY, Chan PK, Leung CB, Szeto CC, Tam JS, Li PK, et al. Parvovirus B19 infection causing red cell aplasia in renal transplantation on tacrolimus. Am J Kidney Dis. 1999 34:1132-6

45. Marchand S, Tchernia G, Hiesse C, Tertian G, Cartron J, Kriaa F, et al. Human parvovirus B19 infection in organ transplant recipients. Clin Transplant. 1999;13:17-24.

46. Keung YK, Chuahirun T, Wesson D. Concomitant parvovirus B19 and cytomegalovirus infections after living-related renal transplantation. Nephrol Dial Transplant. 1999;14:469-71.

47. Moudgil A, Shidban H, Nast CC, Bagga A, Aswad S, Graham SL, et al. Parvovirus B19 infection-related complications in renal transplant recipients: treatment with intravenous immunoglobulin. Transplantation. 1997;64:1847-50.

48. Mathias RS. Chronic anemia as a complication of parvovirus B19 infection in a pediatric kidney transplant patient. Pediatr Nephrol. 1997;11:355-7.

49. Ahsan N, Holman MJ, Gocke CD, Groff JA, Yang HC. Pure red cell aplasia due to parvovirus B19 infection in solid organ transplantation. Clin Transplant. 1997;11:265-70.

50. Bertoni E, Rosati A, Zanazzi M, Azzi A Zakrzewska K Guidi S, et al. Aplastic anemia due to B19 parvovirus infection in cadaveric renal transplant recipients: an underestimated infectious disease in the immunocompromised host. J Nephrol. 1997; 10:152-6.

51. Sturm I, Watschinger B, Geissler K, Guber SE, Popow-Kraupp T, Horl WH, et al. Chronic parvovirus B19 infection-associated pure red cell anaemia in a kidney transplant recipient. Nephrol Dial Transplant. 1996;11:1367-70.

52. Uemura N, Ozawa K, Tani K, Nishikawa M, Inoue S, Nagao T, et al. Pure red cell aplasia caused by parvovirus B19 infection in a renal transplant recipient. Eur J Haematol. 1995;54:68-9.

53. Al-Khaldi N, Watson AR, Harris A, Irving WL. Dual infection with human herpesvirus Type 6 and parvovirus B19 in a renal transplant recipient. Pediatr Nephrol. 1994:8:349-50.

54. Waldman M, Kopp JB. Parvovirus-B19-associated complications in renal transplant recipients. Nat Clin Pract Nephrol. 2007 3:540-50.

55. The World Bank. Available from: http://www.worldbank.org/ en/access-to-information. [Last accessed on 2018 Nov 26].

56. Depasse JW, Lee PT. A model for 'reverse innovation' in health care. Glob Health. 2013:9:40

57. Cavallo R, Merlino C, Re D, Bollero C, Bergallo M, Lembo D, et al. B19 virus infection in renal transplant recipients. J Clin Virol. 2003;26:361-8. 